\title{
Nutritional Research and Fetal Programming: Parental Nutrition Influences the Structure and Function of the Organs
}

\author{
Investigación Nutricional y Programación Fetal: La Nutrición \\ Parental Influye en la Estructura y Función de los Órganos
}

Marcia Barbosa Aguila; Fernanda Ornellas \& Carlos Alberto Mandarim-de-Lacerda

AGUILA, M. B.; ORNELLAS, F. \& MANDARIM-DE-LACERDA, C. A Nutritional research and fetal programming: parental nutrition influences the structure and function of the organs. Int. J. Morphol., 39(1):327-334, 2021.

SUMMARY: Rodents are animals extensively used in biomedical and nutrition research, a necessary step before the research in humans. The composition and type of administration of the experimental diets are relevant and should be thought, considering each type of animal used in the research. It is particularly important to consider, among others, the metabolic differences between species and food needs in macro- and micronutrients to avoid possible bias. The American Institute of Nutrition (AIN) made recommendations for rodents, adapted to the period of growth (AIN-93G), which are pivotal in fetal programming studies. The experiments can be compared among different studies and better translated into humans, considering these limitations in the nutrition of parents and offspring. The review addresses different compositions of experimental food for rodents during development with the ability to induce fetal programming in the offspring and chronic diseases in adulthood due to the nutrition of the mother and father. The 'developmental origins of health and disease' (DOHaD) concept due to maternal nutrition is commented considering the protein restriction, vitamin D restriction, obesity, and intake of fructose or fish-oil. The 'paternal origins of health and disease transmission' (POHaD), because of the nutritional state of the father, were also analyzed in the review, primarily considering the obesity of the father. The review proposes some diet compositions to experimental research considering varied nutritional situations, hoping to assist young researchers or researches not familiar with experimental diet manipulations in the elaboration of the projects.

KEY WORDS: Protein restriction; High-fat diet; High-fructose diet; Vitamin D restriction; Fish oil-rich diet.

\section{INTRODUCTION}

Although there are limitations of generalizing from an animal model to the condition of humans, animals can be useful to get information from a homogeneous group at the same stage of the disease, and free from other puzzling factors (Nevzorova et al., 2020). Life conditions (embryology, anatomy, and physiology) between humans and other mammals might be relatively analogous, indicating the animals as potential models for experimentation (Lorberbaum et al., 2020). An additional advantage of animal models, including nutritional research, is comparing appropriate controls, separating the effect of food intake from other metabolic effects by pair feeding, and the precise manipulation of the diet (Vianna et al., 2016). Likewise, the short life span and genetic and environmental influences in animals can be controlled (Armitage et al., 2004).
The review was thought as a basis for basic scientists focusing on models for epigenetic changes due to dietary manipulations to the mother or father and the consequent programming of diseases in the adulthood offspring (Gusmão-Correia et al., 2012).

Dietary manipulations and rodent experiments. The diets offered to rodents should follow the American Institute of Nutrition (AIN-93G for growth, pregnancy, and lactation; AIN-93M for adult maintenance) to be nutritionally adequate (Reeves et al., 1993).

The age ratio between animals and humans should be well determined for setting up models more analogous in age to humans to translate the findings to humans (Heindel,

Laboratory of Morphometry, Metabolism, and Cardiovascular Disease. Biomedical Center, Institute of Biology. The University of the State of Rio de Janeiro, Rio de Janeiro, Brazil.

Marcia Barbosa Aguila: Orcid0000-0003-3994-4589

Fernanda Ornellas: Orcid0000-0002-9524-5929

Carlos Alberto Mandarim-de-Lacerda: Orcid 0000-0003-4134-7978 
2019). We know that, after the sexual maturity (around two months old to mice) and puberty in humans, an amount of ten days in mice is linked to one year in humans. Thus, mature mice feeding an experimental diet for ten weeks might be generalized to eight years of experimentation in 30-yearold humans (Dutta \& Sengupta, 2016).

The sex of animals should also be considered since fats tend to accumulate in the visceral depots in males but the subcutaneous depots of females. Sex hormones also induce an increase in the fat pads by modulating the distribution of estrogen receptors in the adipocytes (Ornellas et al., 2013; Borges et al., 2020). Hence, experimental manipulations might include alterations in the nutritional status of the pregnant and lactating female and the father.

\section{MATERNAL DIETARY MANIPULATIONS}

Epidemiological reports and experimental studies confirmed that the intrauterine environment has a meaningful and long-term influence on the developing fetus and the promotion of disease in later life (Barker, 1995).

The fetal programming is based on the maternal feeding status during pregnancy and lactation, and the resultant fetal and neonatal nutrition impact, which may cause developmental adaptations and the permanent change in the physiology and metabolism in the offspring (Barker, 1997). The fetal programming would be associated with epigenetic changes during early life (cytosine methylation of DNA, histone posttranslational modifications, and microRNAs), without changes in the DNA sequence (Waterland \& Jirtle, 2004; Aagaard-Tillery et al., 2008).

David Barker introduced the concept that maternal malnourishment and altered infant nutrition can permanently influence offspring metabolism and predispose progeny to the cardiovascular and metabolic diseases (Hales \& Barker, 1992). There is an association between parents' nutrition and progeny health (Ravelli et al., 1998; Brookheart \& Duncan, 2016). Also, the metabolic programming of offspring because of maternal obesity increases the risk of developing major health complications (Ornellas et al., 2015).

The 'Developmental Origins of Health and Disease' $(\mathrm{DOHaD})$ concept helps us better understand the current situation. Epidemiological and experimental evidence indicates a connection between the early-life environment and the metabolic health in adulthood (Plagemann et al., 2012). The 'thrifty phenotype' hypothesis proposed in the early 90 s was essential for the $\mathrm{DOHaD}$ concept by catching the attention of the scientific community to the link between fetal and infant growth, and later life impaired glucose tolerance in adulthood (Hales \& Barker). The adverse nutritional environment in early life creates a situation in which the organism metabolically programmed to cope with low food availability fails to adapt to the energy-rich environment. Contrarily, precocious overnutrition is linked with increasing adipogenesis, eating behavior modification, and appetite control (Gluckman \& Hanson, 2008).

\section{Maternal nutritional restrictions}

Protein. Table I provides examples of experimental diets, considering the background of the AIN-93G formulation. Control and protein restriction diets should be isocaloric, with differences only in protein content. The lipid supplied should guarantee the essential fatty acid amount. Just complex carbohydrates might be added in the form of starch to compensate for the difference in the energy mix, which would not bring any bias to the study. Also, it is necessary to maintain the same protein: lipid: carbohydrate ratio in the studies with a maternal protein restriction diet (Pinheiro et al., 2008; Frantz et al., 2011).

Maternal protein restriction in rodents might have consequences in offspring adulthood, as an Increased susceptibility to obesity (Ozanne et al., 2004; Zambrano et al., 2006), hepatic peroxisome proliferator-activated receptors modifications (Lillycrop et al., 2005), adipocytes with enhanced expression of 11-hydroxysteroid dehydrogenase type 1 , increasing cortisol exposure, and adipocyte proliferation (Reynolds et al., 2001). Also, the maternal protein restriction might affect male and female offspring differently, including differences in the nephron number, and arterial hypertension development (Woods et al., 2005), with impairment of glomerulogenesis (Almeida \& Mandarim-de-Lacerda, 2005a), and cardiac remodeling (Almeida \& Mandarim-de-Lacerda, 2005b).

Vitamin D. Low vitamin D status and obesity have concomitantly reached epidemic levels worldwide, and research linking these two public health issues has grown extensively over the last years (Prasad \& Kochhar, 2016; Savastano et al., 2017).

Vitamin $\mathrm{D}$ is attained through endogenous production or diet, mainly as vitamin D3 (Holick, 2007). In the liver, vitamin $\mathrm{D}$ becomes biologically active as 25 -hydroxyvitamin $\mathrm{D}(25(\mathrm{OH}) \mathrm{D})$, in a first hydroxylation step catalyzed by four enzymes (CYP2R1, CYP27A1, CYP2J6, and CYP3A11) (Schuster, 2011). The second hydroxylation step occurs in the kidney, catalyzed by CYP2B1, then producing 1,25-dihydroxy vitamin $\mathrm{D}(1,25(\mathrm{OH}) 2 \mathrm{D})$, the active form of cholecalciferol, which is a potent activator of the vitamin D receptor (Carlberg \& Muñoz, 2020). The 24-hydroxylase, 
CYP24A1, catabolizes both $25(\mathrm{OH}) \mathrm{D}$ and 1,25 $(\mathrm{OH}) 2 \mathrm{D}$, then generating inactive metabolites (Dusso, 2014).

In obese mice with constant vitamin D3 intake, there is a transient increase of total $25(\mathrm{OH}) \mathrm{D}$ and a decrease of plasmatic vitamin D3 because of the upregulation of 25hydroxylase genes in the liver. The adipose tissue modulates vitamin D metabolism. Therefore, when free $25(\mathrm{OH}) \mathrm{D}$ is diminished, probably Cyp2r1 is the reason (since it is responsible for the production and storage of $25(\mathrm{OH}) \mathrm{D}$ in the adipose tissue) (Bonnet et al., 2019).

Maternal vitamin D restriction leads to the developmental programming of several features of the metabolic syndrome in offspring adulthood (Morris et al., 1995), impairing the pancreas development and mature offspring (insulin-signaling pathway) (Maia-Ceciliano et al., 2016). Besides, maternal vitamin D restriction relates to the glomerular retard maturation by prolonging the period of nephrogenesis (Nascimento et al., 2012), leading to the disarray of pancreatic islet cytoarchitecture with effects on insulin production in the adult mice (Borges et al., 2016).

The vitamin D restricted diet should be produced, thus, without vitamin D in the vitamin mixture (Table I). However, in experimental studies, both the control diet and the vitamin $\mathrm{D}$ restricted diet should be isocaloric (the only difference should be for vitamin $\mathrm{D}$ content), avoiding other biases.

\section{Maternal obesity}

Saturated fatty acid intake. Diet-induced obesity has been a model of obesity often used in mice with translational purposes (Fraulob et al., 2010). Fetal exposure to maternal obesity might initiate a vicious cycle, transmitting metabolic disease across generations and thus exacerbating the epidemic of obesity (Catalano, 2003), which is particularly relevant because women have frequently gone into pregnancy in overweight or obese (Fisher et al., 2013).

Overnutrition mimics the pathophysiology of mammalian obesity because of the excess intake of fat in rodent, including insulin resistance and hyperglycemia (Bringhenti et al., 2013), hepatic and pancreatic fat accumulation (Gregorio et al., 2010, 2013), and higher expression of lipogenic and reduced expression of betaoxidation genes (Volpato et al., 2012).

The intake of a high-fat diet by mother leads to the development of adult offspring hypercholesterolemia, higher adiposity, insulin resistance, and arterial hypertension (Samuelsson et al., 2008). Besides, mice continuously exposed to the high-fat diet through pregnancy, lactation, and post-weaning to adulthood were more likely to develop features comparable to the human metabolic syndrome than mice fed a high-fat diet only post-weaning (Bruce et al., 2009).

Table I. Diet examples of fetal programming studies (to feed mothers during pregnancy and lactation, or fathers). Vitamins and mineral mixes were formulated according to the American Institute of Nutrition AIN-93G for rodents. The protein restriction diet has 5\% energy from protein; the high-fat diet has $49 \%$ energy from lipid, and the high-fructose diet has $45 \%$ of energy from fructose.

\begin{tabular}{|c|c|c|c|c|c|c|}
\hline \multirow[b]{2}{*}{ Ingredients $(\mathrm{g} / \mathrm{kg})$} & \multicolumn{6}{|c|}{ Experimental diets for fetal programming studies } \\
\hline & Control & Protein restriction & High-Fat & High-Fructose & Vitamin D restriction & Fish oil \\
\hline Casein $(>85 \%$ protein $)$ & 200.0 & 50.0 & 230.0 & 200.0 & 200.0 & 200.0 \\
\hline L-cystine & 3.0 & 1.5 & 3.0 & 3.0 & 3.0 & 3.0 \\
\hline Cornstarch & 529.486 & 680.986 & 299.472 & 85.486 & 529.486 & 529.486 \\
\hline Sucrose & 100.0 & 100.0 & 100.0 & 100.0 & 100.0 & 100.0 \\
\hline Fructose & - & - & - & 444.0 & - & - \\
\hline Soybean oil & 70.0 & 70.0 & 70.0 & 70.0 & 70.0 & 7.0 \\
\hline Fish oil & - & - & - & - & - & 63.0 \\
\hline Lard & - & - & 200.0 & - & - & - \\
\hline Fiber & 50.0 & 50.0 & 50.0 & 50.0 & 50.0 & 50.0 \\
\hline Vitamin mixture & 10.0 & 10.0 & 10.0 & 10.0 & $10.0^{*}$ & 10.0 \\
\hline Mineral mixture & 35.0 & 35.0 & 35.0 & 35.0 & 35.0 & 35.0 \\
\hline Choline bitartrate & 2.5 & 2.5 & 2.5 & 2.5 & 2.5 & 2.5 \\
\hline Antioxidant & 0.014 & 0.014 & 0.028 & 0.014 & 0.014 & 0.014 \\
\hline Total (g) & 1000.0 & 1000.0 & 1000.0 & 1000.0 & 1000.0 & 1000.0 \\
\hline Energy $(\mathrm{kcal} / \mathrm{g})$ & 3.95 & 3.95 & 4.95 & 3.95 & 3.95 & 3.95 \\
\hline Carbohydrate (\%Energy) & 64.0 & 78.0 & 32.0 & 64.0 & 64.0 & 64.0 \\
\hline Fructose (\%Energy) & - & - & - & 45.0 & - & - \\
\hline Protein (\%Energy) & 19.0 & 5.0 & 19.0 & 19.0 & 19.0 & 19.0 \\
\hline Lipid (\%Energy) & 17.0 & 17.0 & 49.0 & 17.0 & 17.0 & 17.0 \\
\hline
\end{tabular}


In late pregnancy and early postnatal life, the hypothalamus plasticity is vital in programming appetite, metabolism, and determine a body mass set-point (Keesey \& Hirvonen, 1997). The neonatal exposure to a hypercaloric diet leads to a higher body mass in adulthood (Choi, 2018). Then, the hypothalamus is directly involved with obesity (Velloso, 2012), and the adult offspring of dams fed a highfat diet showed exaggerated feeding response to neuropeptide $\mathrm{Y}$, eating twice as much as control animals (Kozak et al., 2000; Spezani et al., 2020).

Maternal obesity affects male and female offspring differently, with males being more adversely affected than females (Ornellas et al., 2013). Maternal obesity affects the developing fetus with acute hyperglycemia, initiating a betacell compensation, which progresses to beta-cell exhaustion, death, and beta-cell dysfunction, often co-presents with insulin resistance and type 2 diabetes mellitus (Cerf, 2015; Mandarim-de-Lacerda, 2019).

Fish oil intake. Fish oil is a source of $n-3$ polyunsaturated fatty acids (n-3 PUFA [alpha linolenic acid (LNA, 18:3 n3), eicosapentaenoic acid (EPA, 20:5 n3), and docosahexaenoic acid (DHA, 22:6 n3)].

Fish oil has a potent well-characterized hypolipidemic action, decreasing adiposity and serum lipids in mice (Bargut et al., 2015, 2016a) and humans (Couet et al., 1997). N-3 fatty acids, LNA, EPA, and DHA, are essential fatty acids with several health benefits (Bremer et al., 2014). They form the structural component of cell membranes, affecting its fluidity, development, cognitive, and visual functions (Noakes et al., 2012). Besides, n-3 PUFA causes a hypolipidemic effect related to the transcriptional factors that are significant regulators of the hepatic metabolism of lipids (peroxisome proliferator-activated receptors, sterol regulatory element-binding protein, and liver $\mathrm{X}$ receptor) (Jump, 2008).

EPA and DHA have multiple well-established health benefits, as anti-obesity (Bargut et al., 2016b), antihypertensive (Medeiros et al., 2005), and antiinflammatory effects in white adipose tissue, diminishing markers of activation of mitogen-activated protein kinase, local renin-angiotensin system, and infiltration of macrophages (Bargut et al., 2015). The high intake of longchain n-3 PUFAs during pregnancy might reduce adult disease risks in rat offspring (Joshi et al., 2003).

In experimental studies, the control diet and fish oilenriched diet should be isocaloric, and their difference should only exist in the proportion of soybean oil and fish oil content (Table I). The soybean oil added to the diet could be manipulated to compensate for the addition of fish oil and maintain the total amount of lipids in the fish oil diet.

Maternal fructose intake. Fructose has become a significant ingredient of the modern human diet, while it was almost absent in the diet until a few years ago, because of the low cost of fructose (corn syrup), which results from the processing of corn (Marshall \& Kooi, 1957; Livesey \& Taylor, 2008).

Converting doses of macronutrients between different species should consider the caloric intake. An adult mouse should have a daily intake of approximately $12 \mathrm{kcal}$, and around $2400 \mathrm{kcal}$ for an adult human (Jang et al., 2018). Consequently, $0.5 \mathrm{~g} / \mathrm{kg}$ of fructose in mice corresponds to approximately $0.5 \%$ of daily calorie intake, which is equivalent to a person to $3 \mathrm{~g}$ of fructose (Marriott et al., 2009).

Exposure to high levels of fructose during critical periods of development might lead to obesity through the direct effect of fructose on adipose tissue and the developing hypothalamus, disrupting endocrine signaling between adipose tissue and hypothalamus (Goran et al., 2013). Maternal high-fructose intake results in hyperinsulinemia at weaning and increased leptinemia in rodent offspring adulthood (Vickers et al., 2011). Besides, the consumption of a high-fructose diet by the mother or father leads to adverse effects on liver metabolism in adult offspring. When both mother and father are fed the fructose diet, the adverse effects on the offspring are more severe (Carapeto et al., 2018).

It is noteworthy to remark that high dietary fructose intake in rodents enhances plasmatic uric acid level, and simultaneously hyperuricemia and insulin resistance develop (Nakagawa et al., 2006), then arterial hypertension and improved sympathetic nervous system activity and kidney sodium reabsorption (Magliano et al., 2015).

In Table I, fructose was added in powder, and the complex carbohydrates were reduced to provide isocaloric diets, avoiding bias in the study. In fructose-rich diets, to change only one variable, it is possible to add an amount of fructose and removed the equivalent amount of cornstarch (Maia-Ceciliano et al., 2019; Ornellas et al., 2020). Studies that administer fructose in drinking water should consider that, in this case, control of the amount of fructose ingested is lost, which can make reproducibility and interpretation of results difficult.

PATERNAL DIETARY MANIPULATIONS. Mammals might have a non-genetic, intergenerational communication of metabolic changes in obesity from father to offspring $(\mathrm{Ng}$ 
et al., 2010; Ornellas et al., 2018). Data from animal models are progressively providing evidence that the spermatozoon is not a passive component in the development of the embryo, as well as paternal experiences preconception might affect the developing embryo and fetal uterine growth (Ornellas et al., 2015, 2018).

The epigenetic information contained in the male gamete and transmitted to the zygote through copulation makes possible the paternal origin of health and disease transmission or $\mathrm{POHaD}$, allowing the fetal programming induced by the obese father (Soubry, 2018). The phenotypic transmission is related to epigenetics, the mechanism that does not change the DNA structural sequence, but is transmissible and causes a reversible change in the gene expressions (McPherson et al., 2014).

Moreover, the origin and transmission of paternally mediated pathologies to offspring might be related to the aberrant repair of spermatozoon DNA damage (Aitken et al., 2004). The first step in this process requires imperfect chromatin remodeling through spermiogenesis resulting in spermatozoa released into the seminiferous tubules in an imperfect state and adverse compaction of chromatin. The defective chromatin remodeling increases the spermatozoa susceptibility to DNA strand breaks, mediated by oxidative stress, enhancing spermatozoon apoptosis and oxidative DNA damage. The oocyte presents a limited capacity to repair the oxidized DNA damage brought into the zygote by the fertilizing spermatozoon. Therefore, incomplete or aberrant repair of paternal DNA damage might generate mutations that will affect every cell in the body because it precedes the $\mathrm{S}$ phase in the first mitotic division (Aitken, 2004).

Male obesity negatively impacts the sperm molecular composition and function, decreasing the spermatozoa motility, count, usual morphology, ability to capacitate and bind to an oocyte, also increasing sperm reactive oxidative species-associated DNA damage, and mitochondrial dysfunction (Palmer et al., 2012). Both obese humans and rodents might have enhanced oxidative spermatozoon DNA damage. Male obesity is multifactorial, with changes in DNA methylation and a range of post translational modifications affecting chromatin-associated proteins. Besides, sperm short non-coding RNAs (miRNAs) are a distinct subspecies sensitive to environmental adjustments, and obesity alters the profile in sperm. Once transferred into the zygote, miRNAs might cause embryonic epigenetic changes, thus altering fetus development (Dupont et al., 2019).

The connection between paternal health and offspring outcomes seemed to be sex-dependent and have initially been reported in epidemiological studies. Indeed, murine models have reinforced the hypothesis that paternal obesity could exert transgenerational and sex-specific effects on offspring health (Ornellas et al., 2018). Besides, there is an association between paternal obesity and pancreatic beta-cell dysfunction without altering growth or adiposity in female rat offspring ( $\mathrm{Ng}$ et al.). However, both sexes offspring of obese fathers are hyperglycemic, glucose intolerant, with high levels of total cholesterol and triacylglycerols, although obesity is not present (Tarevnic et al., 2018).

FINAL REMARKS. In biomedical and nutrition research, rodents are regularly used even in fetal programming studies, as a vital step to cross before to research in humans. Thus, it is logical that the composition and type of administration of the diets are relevant and should be specified for the type of animal used in the research, such as metabolic differences between species and food needs in macro- and micronutrients. The AIN recommendations for rodents are adapted to the period of growth or maintenance of the mature animal, which is particularly significant in fetal programming studies. This review was prepared to assist young researchers or researches not familiar with nutritional manipulations in the elaboration of their projects.

FUNDING. MBA and CAML are supported by Conselho Nacional de Desenvolvimento Científico e Tecnológico (Brazil) (CNPq, Grant numbers 302.920/2016-1 and 40.60.81/2018-2 to CML; 305.865/2017-0 to MBA), Fundação Carlos Chagas Filho de Amparo à Pesquisa do Estado do Rio de Janeiro (Faperj, Grant numbers E-26/ 202.935/2017 to CAML, and E-26/202.795/2017 to MBA). These foundations had no interference in the accomplishment and submission of the study.

AGUILA, M. B.; ORNELLAS, F. \& MANDARIM-DELACERDA, C. A Investigación nutricional y programación fetal: La nutrición parental influye en la estructura y función de los órganos. Int. J. Morphol., 39 (1):327-334, 2021.

RESUMEN: Los roedores son animales utilizados frecuentemente en la investigación biomédica y nutricional, un paso necesario antes de la investigación en humanos. La composición y el tipo de administración de las dietas experimentales son relevantes y se debe considerar cada tipo de animal utilizado en los estudios. Es particularmente importante considerar las diferencias metabólicas entre las especies y las necesidades alimentarias de macro y micronutrientes para evitar posibles sesgos. El Instituto Americano de Nutrición (AIN) estableció recomendaciones para los roedores, adaptadas al período de crecimiento (AIN-93G), que son fundamentales en los estudios de programación fetal. Los experimentos se pueden comparar entre diferentes estudios y aplicar en humanos, considerando estas limitaciones en la nutrición de padres e hijos. La revisión aborda diferentes composiciones de ali- 
mentos para estudios experimentales en roedores durante su desarrollo, con la capacidad de inducir programación fetal en la descendencia y enfermedades crónicas en la adultez, considerando la nutrición de los padres. El concepto de 'orígenes del desarrollo de la salud y la enfermedad' (DOHaD) debido a la nutrición materna se comenta considerando la restricción de proteínas, la restricción de vitamina $\mathrm{D}$, la obesidad y la ingesta de fructosa o aceite de pescado. Los 'orígenes paternos de la salud y transmisión de enfermedades' (POHaD), debido al estado nutricional del padre, también fueron analizados considerando principalmente la obesidad del padre. La revisión propone algunas composiciones dietéticas a la investigación experimental considerando situaciones nutricionales variadas, con la esperanza de ayudar a jóvenes investigadores o investigadores no familiarizados con las manipulaciones experimentales de la dieta en la elaboración de los proyectos.

PALABRAS CLAVE: Restricción de proteínas; Dieta alta en grasas; Dieta rica en fructosa; Restricción de vitamina D; Dieta rica en aceite de pescado.

\section{REFERENCES}

Aagaard-Tillery, K. M.; Grove, K.; Bishop, J.; Ke, X.; Fu, Q.; McKnight, R. \& Lane, R. H. Developmental origins of disease and determinants of chromatin structure: maternal diet modifies the primate fetal epigenome. J. Mol. Endocrinol., 41(2):91-102, 2008.

Aitken, R. J. Founders' Lecture. Human spermatozoa: fruits of creation, seeds of doubt. Reprod. Fertil. Dev., 16(7):655-64, 2004.

Aitken, R. J.; Koopman, P. \& Lewis, S. E. M. Seeds of concern. Nature, 432(7013):48-52, 2004.

Almeida, J. R. \& Mandarim-de-Lacerda, C. A. Maternal gestational proteincalorie restriction decreases the number of glomeruli and causes glomerular hypertrophy in adult hypertensive rats. Am. J. Obstet. Gynecol., 192(3):945-51, 2005a.

Almeida, J. R. \& Mandarim-de-Lacerda, C. A. Overweight is genderdependent in prenatal protein--calorie restricted adult rats acting on the blood pressure and the adverse cardiac remodeling. Life Sci., 77(12):1307-18, 2005 b.

Armitage, J. A.; Khan, I. Y.; Taylor, P. D.; Nathanielsz, P. W. \& Poston, L. Developmental programming of the metabolic syndrome by maternal nutritional imbalance: how strong is the evidence from experimental models in mammals? J. Physiol., 561(Pt. 2):355-77, 2004.

Bargut, T. C. L.; Mandarim-de-Lacerda, C. A. \& Aguila, M. B. A highfish-oil diet prevents adiposity and modulates white adipose tissue inflammation pathways in mice. J. Nutr. Biochem., 26(9):960-9, 2015.

Bargut, T. C. L.; Silva-e-Silva, A. C. A.; Souza-Mello, V.; Mandarim-deLacerda, C. A. \& Aguila, M. B. Mice fed fish oil diet and upregulation of brown adipose tissue thermogenic markers. Eur. J. Nutr., 55(1):159$69,2016 \mathrm{a}$

Bargut, T. C. L.; Souza-Mello, V.; Mandarim-de-Lacerda, C. A. \& Aguila, M. B. Fish oil diet modulates epididymal and inguinal adipocyte metabolism in mice. Food Funct., 7(3):1468-76, 2016b.

Barker, D. J. The Wellcome Foundation Lecture, 1994. The fetal origins of adult disease. Proc. Biol. Sci., 262(1363):37-43, 1995.

Barker, D. J. Maternal nutrition, fetal nutrition, and disease in later life. Nutrition, 13(9):807-13, 1997

Bonnet, L.; Hachemi, M. A.; Karkeni, E.; Couturier, C.; Astier, J.; Defoort, C.; Svilar, L.; Martin, J. C.; Tourniaire, F. \& Landrier, J. F. Diet-induced obesity modifies vitamin D metabolism and adipose tissue storage in mice. J. Steroid Biochem. Mol. Biol., 185:39-46, 2019.
Borges, C. C.; Bringhenti, I.; Aguila, M. B. \& Mandarim-de-Lacerda, C. A. Vitamin D restriction enhances periovarian adipose tissue inflammation in a model of menopause. Climacteric, 23(1):99-104, 2020.

Borges, C. C.; Salles, A. F.; Bringhenti, I.; Souza-Mello, V.; Mandarim-deLacerda, C. A. \& Aguila, M. B. Adverse effects of vitamin D deficiency on the Pi3k/Akt pathway and pancreatic islet morphology in dietinduced obese mice. Mol. Nutr. Food Res., 60(2):346-57, 2016.

Bremer, A. A.; Stanhope, K. L.; Graham, J. L.; Cummings, B. P.; Ampah, S. B.; Saville, B. R. \& Havel, P. J. Fish oil supplementation ameliorates fructose-induced hypertriglyceridemia and insulin resistance in adult male rhesus macaques. J. Nutr., 144(1):5-11, 2014.

Bringhenti, I.; Moraes-Teixeira, J. A.; Cunha, M. R.; Ornellas, F.; Mandarimde-Lacerda, C. A. \& Aguila, M. B. Maternal obesity during the preconception and early life periods alters pancreatic development in early and adult life in male mouse offspring. PLoS One, 8(1):e55711, 2013.

Brookheart, R. T. \& Duncan, J. G. Modeling dietary influences on offspring metabolic programming in Drosophila melanogaster. Reproduction, 152(3):R79-90, 2016.

Bruce, K. D.; Cagampang, F.R.; Argenton, M.; Zhang, J.; Ethirajan, P. L.; Burdge, G. C.; Bateman, A. C.; Clough, G. F.; Poston, L.; Hanson, M. A.; et al. Maternal high-fat feeding primes steatohepatitis in adult mice offspring, involving mitochondrial dysfunction and altered lipogenesis gene expression. Hepatology, 50(6):1796-808, 2009.

Carapeto, P. V.; Ornellas, F.; Mandarim-de-Lacerda, C. A. \& Aguila, M. B. Liver metabolism in adult male mice offspring: consequences of a maternal, paternal or both maternal and paternal high-fructose diet. J. Dev. Orig. Health Dis., 9(4):450-9, 2018.

Carlberg, C. \& Muñoz, A. An update on vitamin D signaling and cancer. Semin. Cancer Biol., 2020. DOI: https://www.doi.org/10.1016/ j.semcancer.2020.05.018

Catalano, P. M. Obesity and pregnancy--the propagation of a vicious cycle? J. Clin. Endocrinol. Metab., 88(8):3505-6, 2003.

Cerf, M. E. High-fat programming of beta-cell compensation, exhaustion, death, and dysfunction. Pediatr. Diabetes, 16(2):71-8, 2015.

Choi, J. S. Effects of maternal and post-weaning high-fat diet on leptin resistance and hypothalamic appetite genes in sprague dawley rat offspring. Clin. Nutr. Res., 7(4):276-90, 2018.

Couet, C.; Delarue, J.; Ritz, P.; Antoine, J. M. \& Lamisse, F. Effect of dietary fish oil on body fat mass and basal fat oxidation in healthy adults. Int. J. Obes., 21:637-43, 1997.

Dupont, C.; Kappeler, L.; Saget, S.; Grandjean, V. \& Levy, R. Role of miRNA in the Transmission of Metabolic Diseases Associated With Paternal Diet-Induced Obesity. Front. Genet., 10:337, 2019.

Dusso, A. S. Update on the biologic role of the vitamin D endocrine system. Curr. Vasc. Pharmacol., 12(2):272-7, 2014.

Dutta, S. \& Sengupta, P. Men, and mice: relating their ages. Life Sci., 152: 244-8, 2016.

Fisher, S. C.; Kim, S. Y.; Sharma, A. J.; Rochat, R. \& Morrow, B. Is obesity still increasing among pregnant women? Prepregnancy obesity trends in 20 states, 2003-2009. Prev. Med., 56(6):372-8, 2013.

Frantz, E. D. C.; Aguila, M. B.; Pinheiro-Mulder, A. R. \& Mandarim-deLacerda, C. A. Transgenerational endocrine pancreatic adaptation in mice from maternal protein restriction in utero. Mech. Ageing Dev., 132(3):110-6, 2011.

Fraulob, J. C.; Ogg-Diamantino, R.; Fernandes-Santos, C.; Aguila, M. B. $\&$ Mandarim-de-Lacerda, C. A. A mouse model of metabolic syndrome: insulin resistance, fatty liver and non-alcoholic fatty pancreas disease (NAFPD) in C57BL/6 mice fed a high-fat diet. J. Clin. Biochem. Nutr., 46(3):212-23, 2010

Gluckman, P. D. \& Hanson, M. A. Developmental and epigenetic pathways to obesity: an evolutionary-developmental perspective. Int. J. Obes. (Lond.), 32 Suppl. 7:S62-71, 2008.

Goran, M. I.; Dumke, K.; Bouret, S. G.; Kayser, B.; Walker, R. W. \& Blumberg, B. The obesogenic effect of high fructose exposure during early development. Nat. Rev. Endocrinol., 9(8):494-500, 2013. 
Gregorio, B. M.; Souza-Mello, V.; Carvalho, J. J.; Mandarim-de-Lacerda, C. A. \& Aguila, M. B. Maternal high-fat intake predisposes nonalcoholic fatty liver disease in C57BL/6 offspring. Am. J. Obstet. Gynecol., 203(5):495.e1-8, 2010.

Gregorio, B. M.; Souza-Mello, V.; Mandarim-de-Lacerda, C. A. \& Aguila, M. B. Maternal high-fat diet is associated with altered pancreatic remodelling in mice offspring. Eur. J. Nutr., 52(2):759-69, 2013.

Gusmão-Correia, M. L.; Volpato, A. M.; Aguila, M. B. \& Mandarim-deLacerda, C .A. Developmental origins of health and disease: experimental and human evidence of fetal programming for metabolic syndrome. J. Hum. Hypertens., 26(7):405-19, 2012.

Hales, C. N. \& Barker, D. J. Type 2 (non-insulin-dependent) diabetes mellitus: the thrifty phenotype hypothesis. Diabetologia, 35:595-601, 1992.

Heindel, J. J. The developmental basis of disease: Update on environmental exposures and animal models. Basic Clin. Pharmacol. Toxicol., 125 Suppl. 3:5-13, 2019.

Holick, M. F. Vitamin D deficiency. N. Engl. J. Med., 357(3):266-81, 2007.

Jang, C.; Hui, S.; Lu, W.; Cowan, A. J.; Morscher, R. J.; Lee, G.; Liu, W.; Tesz, G. J.; Birnbaum, M. J. \& Rabinowitz, J. D. The small intestine converts dietary fructose into glucose and organic acids. Cell Metab., 27(2):351-61.e3, 2018.

Joshi, S.; Rao, S.; Golwilkar, A.; Patwardhan, M. \& Bhonde, R. Fish oil supplementation of rats during pregnancy reduces adult disease risks in their offspring. J. Nutr., 133(10):3170-4, 2003.

Jump, D. B. N-3 polyunsaturated fatty acid regulation of hepatic gene transcription. Curr. Opin. Lipidol., 19(3):242-7, 2008.

Keesey, R. E. \& Hirvonen, M. D. Body weight set-points: determination and adjustment. J. Nutr., 127(9):1875S-83S, 1997.

Kozak, R.; Burlet, A.; Burlet, C. \& Beck, B. Dietary composition during fetal and neonatal life affects neuropeptide $\mathrm{Y}$ functioning in adult offspring. Brain Res. Dev. Brain Res., 125(1-2):75-82, 2000.

Lillycrop, K. A.; Phillips, E. S.; Jackson, A. A.; Hanson, M. A. \& Burdge, G. C. Dietary protein restriction of pregnant rats induces and folic acid supplementation prevents epigenetic modification of hepatic gene expression in the offspring. J. Nutr., 135(6):1382-6, 2005.

Livesey, G. \& Taylor, R. Fructose consumption and consequences for glycation, plasma triacylglycerol, and body weight: meta-analyses and meta-regression models of intervention studies. Am. J. Clin. Nutr., 88(5):1419-37, 2008.

Lorberbaum, D. S.; Docherty, F. M. \& Sussel, L. Animal models of pancreas development, developmental disorders, and disease. Adv. Exp. Med. Biol., 1236:65-85, 2020.

Magliano, D. C.; Penna-de-Carvalho, A.; Vazquez-Carrera, M.; Mandarimde-Lacerda, C. A. \& Aguila, M. B. Short-term administration of GW501516 improves inflammatory state in white adipose tissue and liver damage in high-fructose-fed mice through modulation of the reninangiotensin system. Endocrine, 50(2):355-67, 2015.

Maia-Ceciliano, T. C.; Dutra, R. R.; Aguila, M. B. \& Mandarim-De-Lacerda, C. A. The deficiency and the supplementation of vitamin D and liver: Lessons of chronic fructose-rich diet in mice. J. Steroid Biochem. Mol. Biol., 192:105399, 2019.

Maia-Ceciliano, T. C.; Vianna, A. R.; Barbosa-da-Silva, S.; Aguila, M. B.; Faria, T. S. \& Mandarim-de-Lacerda, C. A. Maternal vitamin Drestricted diet has consequences in the formation of pancreatic islet/ insulin-signaling in the adult offspring of mice. Endocrine, 54(1):609, 2016.

Mandarim-de-Lacerda, C. A. Pancreatic islet (of Langerhans) revisited. Histol. Histopathol., 34(9):985-93, 2019.

Marriott, B. P.; Cole, N. \& Lee, E. National estimates of dietary fructose intake increased from 1977 to 2004 in the United States. J. Nutr., 139(6):1228S-35S, 2009.

Marshall, R. O. \& Kooi, E. R. Enzymatic conversion of D-glucose to Dfructose. Science, 125(3249):648-9, 1957.

McPherson, N. O.; Fullston, T.; Aitken, R. J. \& Lane, M. Paternal obesity, interventions, and mechanistic pathways to impaired health in offspring. Ann. Nutr. Metab., 64(3-4):231-8, 2014.
Medeiros, F. J.; Mothé, C. G.; Aguila, M. B. \& Mandarim-de-Lacerda, C. A. Long-term intake of edible oils benefits blood pressure and myocardial structure in spontaneously hypertensive rat (SHR) and streptozotocin diabetic SHR. Prostaglandins Other Lipid Mediat., 78(14):231-48, 2005.

Morris, G. S.; Zhou, Q.; Hegsted, M. \& Keenan, M. J. Maternal consumption of a low vitamin D diet retards metabolic and contractile development in the neonatal rat heart. J. Mol. Cell. Cardiol., 27(6):1245-50, 1995.

Nakagawa, T.; Hu, H.; Zharikov, S.; Tuttle, K. R.; Short, R. A.; Glushakova, O.; Ouyang, X.; Feig, D. I.; Block, E. R.; Herrera-Acosta, J.; et al. A causal role for uric acid in fructose-induced metabolic syndrome. Am. J. Physiol. Renal Physiol., 290(3):F625-31, 2006.

Nascimento, F. A. M.; Maia-Ceciliano, T. C.; Aguila, M. B. \& Mandarimde-Lacerda, C. A. Maternal vitamin D deficiency delays glomerular maturity in F1 and F2 offspring. PLoS One, 7(8):e41740, 2012.

Nevzorova, Y. A.; Boyer-Diaz, Z.; Cubero, F. J. \& Gracia-Sancho, J. Animal models for liver disease - A practical approach for translational research. J. Hepatol., 73(2):423-40, 2020.

Ng, S. F.; Lin, R. C. Y.; Laybutt, D. R.; Barres, R.; Owens, J. A. \& Morris, M. J. Chronic high-fat diet in fathers programs beta-cell dysfunction in female rat offspring. Nature, 467(7318):963-6, 2010.

Noakes, P. S.; Vlachava, M.; Kremmyda, L. S.; Diaper, N. D.; Miles, E. A.; Erlewyn-Lajeunesse, M.; Williams, A. P.; Godfrey, K. M. \& Calder, P. C. Increased intake of oily fish in pregnancy: effects on neonatal immune responses and on clinical outcomes in infants at $6 \mathrm{mo}$. Am. J. Clin. Nutr., 95(2):395-404, 2012.

Ornellas, F.; Bringhenti, I.; Mattos, B.; Mandarim-de-Lacerda, C. A. \& Aguila, M. B. Father's obesity programs the adipose tissue in the offspring via the local renin-angiotensin system and MAPKs pathways, especially in adult male mice. Eur. J. Nutr., 57(5):1901-12, 2018.

Ornellas, F.; Carapeto, P. V.; Aguila, M. B. \& Mandarim-de-Lacerda, C. A. Sex-linked changes and high cardiovascular risk markers in the mature progeny of father, mother, or both father and mother consuming a highfructose diet. Nutrition, 71:110612, 2020.

Ornellas, F.; Mello, V. S.; Mandarim-de-Lacerda, C. A. \& Aguila, M. B. Sexual dimorphism in fat distribution and metabolic profile in mice offspring from diet-induced obese mothers. Life Sci., 93(12-14):45463, 2013.

Ornellas, F.; Souza-Mello, V.; Mandarim-de-Lacerda, C. A. \& Aguila, M. B. Programming of obesity and comorbidities in the progeny: lessons from a model of diet-induced obese parents. PLoS One, 10(4):e124737, 2015.

Ozanne, S. E.; Lewis, R.; Jennings, B. J. \& Hales, C. N. Early programming of weight gain in mice prevents the induction of obesity by a highly palatable diet. Clin. Sci. (Lond.), 106(2):141-5, 2004.

Palmer, N. O.; Bakos, H. W.; Fullston, T. \& Lane, M. Impact of obesity on male fertility, sperm function, and molecular composition. Spermatogenesis, 2(4):253-63, 2012.

Pinheiro, A. R.; Salvucci, I. D. M.; Aguila, M. B. \& Mandarim-deLacerda, C. A. Protein restriction during gestation and/or lactation causes adverse transgenerational effects on biometry and glucose metabolism in F1 and F2 progenies of rats. Clin. Sci. (Lond.), 114(5):381-92, 2008.

Plagemann, A.; Harder, T.; Schellong, K.; Schulz, S. \& Stupin, J. H. Early postnatal life as a critical time window for determination of long-term metabolic health. Best Pract. Res. Clin. Endocrinol. Metab., 26(5):64153, 2012.

Prasad, P. \& Kochhar, A. Interplay of vitamin D and metabolic syndrome: A review. Diabetes Metab. Syndr, 10(2):105-12, 2016.

Ravelli, A. C.; van der Meulen, J. H.; Michels, R. P.; Osmond, C.; Barker, D. J.; Hales, C. N. \& Bleker, O. P. Glucose tolerance in adults after prenatal exposure to famine. Lancet, 351(9097):173-7, 1998.

Reeves, P. G.; Nielsen, F. H. \& Fahey Jr., G. C. AIN-93 purified diets for laboratory rodents: final report of the American Institute of Nutrition ad hoc writing committee on the reformulation of the AIN-76A rodent diet. J. Nutr., 123(11):1939-51, 1993. 
Reynolds, R. M.; Walker, B. R.; Syddall, H. E.; Andrew, R.; Wood, P. J.; Whorwood, C.B . \& Phillips, D. I. Altered control of cortisol secretion in adult men with low birth weight and cardiovascular risk factors. $J$. Clin. Endocrinol. Metab., 86(1):245-50, 2001.

Samuelsson, A. M.; Matthews, P. A.; Argenton, M.; Christie, M. R.; McConnell, J. M.; Jansen, E. H.; Piersma, A. H.; Ozanne, S. E.; Twinn, D. F.; Remacle, C.; et al. Diet-induced obesity in female mice leads to offspring hyperphagia, adiposity, hypertension, and insulin resistance: a novel murine model of developmental programming. Hypertension, 51(2):383-92, 2008.

Savastano, S.; Barrea, L.; Savanelli, M. C.; Nappi, F.; Di Somma, C.; Orio, F. \& Colao, A. Low vitamin D status and obesity: Role of nutritionist. Rev. Endocr. Metab. Disord., 18(2):215-25, 2017.

Schuster, I. Cytochromes P450 are essential players in the vitamin D signaling system. Biochim. Biophys. Acta, 1814(1):186-99, 2011.

Soubry, A. Epigenetics as a Driver of Developmental Origins of Health and Disease: Did We Forget the Fathers? Bioessays, 40(1), 2018.

Spezani, R.; da Silva, R. R.; Martins, F. F.; de Souza Marinho, T.; Aguila, M. B. \& Mandarim-de-Lacerda, C. A. Intermittent fasting, adipokines, insulin sensitivity, and hypothalamic neuropeptides in a dietary overload with high-fat or high-fructose diet in mice. J. Nutr. Biochem., 83:108419, 2020.

Tarevnic, R.; Ornellas, F.; Mandarim-de-Lacerda, C. A. \& Aguila, M. B. Beneficial effects of maternal swimming during pregnancy on offspring metabolism when the father is obese. J. Dev. Orig. Health Dis., 10(4):502-6, 2018.

Velloso, L. A. Maternal consumption of high-fat diet disturbs hypothalamic neuronal function in the offspring: implications for the genesis of obesity. Endocrinology, 153(2):543-5, 2012.

Vianna, A. R. C. B.; Aguila, M. B. \& Mandarim-de-Lacerda, C. A. Effects of liraglutide in hypothalamic arcuate nucleus of obese mice. Obesity (Silver Spring), 24(3):626-33, 2016.

Vickers, M. H.; Clayton, Z. E.; Yap, C. \& Sloboda, D. M. Maternal fructose intake during pregnancy and lactation alters placental growth and leads to sex-specific changes in fetal and neonatal endocrine function. Endocrinology, 152(4):1378-87, 2011.

Volpato, A. M.; Schultz, A.; Magalhaes-da-Costa, E.; Correia, M. L.; Aguila, M. B. \& Mandarim-de-Lacerda, C. A. Maternal high-fat diet programs for metabolic disturbances in offspring despite leptin sensitivity. Neuroendocrinology, 96(4):272-84, 2012.

Waterland, R. A. \& Jirtle, R. L. Early nutrition, epigenetic changes at transposons and imprinted genes, and enhanced susceptibility to adult chronic diseases. Nutrition, 20(1):63-8, 2004.

Woods, L. L.; Ingelfinger, J. R. \& Rasch, R. Modest maternal protein restriction fails to program adult hypertension in female rats. Am. $J$. Physiol. Regul. Integr. Comp. Physiol., 289(4):R1131-6, 2005.

Zambrano, E.; Bautista, C. J.; Deás, M.; Martinez-Samayoa, P. M.; Gonzalez-Zamorano, M.; Ledesma, H.; Morales, J.; Larrea, F. \& Nathanielsz, P. W. A low maternal protein diet during pregnancy and lactation has sex-and window of exposure-specific effects on offspring growth and food intake, glucose metabolism and serum leptin in the rat. J. Physiol., 571(Pt. 1):221-30, 2006.
Corresponding author:

Carlos Alberto Mandarim-de-Lacerda

Universidade do Estado do Rio de Janeiro

Centro Biomedico, Instituto de Biologia

Laboratorio de Morfometria

Metabolismo e Doença Cardiovascular

Av 28 de Setembro 87 fds.

Rio de Janeiro

RJ (20551-030)

BRAZIL

Webpage: www.Immc.uerj.br

\author{
Email: mandarim@uerj.br \\ mandarim.ca@gmail.com
}

Received: 19-09-2020

Accepted: 14-10-2020 